MedieKultur | Journal of media and communication research | ISSN 1901-9726

Article

\title{
Discourses of positionality and the challenges of democratization in the global south: The case of Nepal and Cameroon
}

\section{Teke Ngomba \& Jacob Thorsen}

MedieKultur 2012, 52, 62-80

Published by SMID | Society of Media researchers In Denmark | www.smid.dk The online version of this text can be found open access at www.mediekultur.dk

In this article, we argue that to conceptually and empirically grasp the dynamics and challenges of processes of civic participation, i.e., the deliberation and empowerment of disenfranchised and marginalized populations in the Global South, communication for social change scholars need to pay more attention to three issues: the quality of citizens' self-perceptions in relation to their local milieu, inter-citizen perceptions and relations at the local level and lastly, the attendant consequences of these on citizens' sense of efficacy. To grasp and comprehend the interplay of these three issues, we propose the adoption of Floya Anthias' concept of narratives of location and positionality and demonstrate the heuristic vitality of this notion through a discussion of some local discourses of positionality in Nepal and Cameroon.

\section{Introduction}

Among the many challenges that countries in the Global South face, two central ones stand out: the challenge to sustainably entrench democratic values and practices and the challenge to sustainably tackle socio-economic development problems especially at the local level. At the moment, a recurrent perspective within academic and policy-making circles is that, for these challenges to be tackled, approaches to them need to be participatory. 
The central logic underpinning this recurrent perspective revolves around the ideal that development is in itself participatory and that for it to be sustainable, it "must entail open dialogue and broadly civic engagement" (Stiglitz, 2002, p. 165) through which people, "in partnership with each other and those able to assist them, identify problems and needs, mobilize resources and assume responsibility themselves to plan; manage; control and assess the individual and collective actions that they decide upon" (Brett, 2003, p. 5).

Similarly, given that communication is an indispensable part of development processes (see Gumucio-Dragon, 2009, p. 452), the main argument contemporarily has also been that communication strategies for local development need to be participatory. The central logic in this argument is that rather than being a "vertical process of information transmission" from the "knowledgeable to the less knowledgeable" (Morris, 2003, p. 226), communication for development needs to be "more dialogical and community-based" (Jacobson \& Storey, 2004, p. 99; see also Waisbord, 2008, p. 507). Framed contemporarily as communication for social change, this approach to communication in development processes is basically about people "taking into their own hands the communication processes that will allow them to make their voices heard, to establish horizontal dialogues with planners and development specialists, to take decisions on the development issues that affect their lives [and] to ultimately achieve social changes for the benefit of their community" (Gumucio-Dragon, 2009, p. 453; see also Barranquero, 2009, p. 651; and Rodríguez, 2001, p. 34).

Notwithstanding the preponderance of recommendations (and pressures) for development stakeholders in the Global South to adopt the above-mentioned participatory approaches to tackle the development problems confronting them, there remain "significant challenges to the systematic and effective inclusion of local communities and households" in development processes in the Global South (Nelson et al., 2009, p. 386). Given this state of affairs, two questions are raised: why is this so and what conditions really discourage the adoption of participatory approaches to development and communication for social change? (For similar questions, see for instance, Waisbord, 2008, p. 506 and GumucioDragon, 2009, p. 454).

Understandably, there are for instance, several institutional and legislative imperatives, which need to be in place for participatory approaches to development, democracy, and communication to effectively take place (see Docherty et al., 2001; Gumucio-Dragon, 2009; and Waisbord, 2008). But because participation and mobilization by their very basic nature involve parameters of inter-citizen interaction revolving around the imperatives of dialogue, equity, tolerance, respect, and having "mutual trust" (Msibi \& Penzhorn, 2010, p. 226; see also Dahlgren, 2000, pp. 337-338; and Gumucio-Dragon, 2009, p. 454), there is a need for more and deeper examinations of the quality of inter-citizen perception and interaction at the local level and the implications of these on processes of participatory development, democracy, and communication for social change in the Global South.

Focusing on these issues is all the more important given that most countries in the Global South tend to have long histories of exclusion and marginalization on political, regional, 
ethnic, tribal, gender, and/or generational lines. Such historical "baggage" of marginalization and inequality fuse with uncertainties of the transitional era in which these countries currently operate and the outcome of this with regards to the nature of inter-citizen perception and interaction can either be a force for good or ill as attempts are made to entrench local processes of participatory democracy and development. In Nepal for instance, contemporary inter-citizen interactions take place in the context of a long history of a castebased social system fraught with marginalization and a post-conflict scenario given that the country is just coming out of several years of civil war, which left an estimated thirteen thousand people dead and ended the rule of the monarchy.

Following from the above, it is clear that to entrench our understanding of the processes and challenges of furthering participatory development, democracy and communication for social change, scholars, in particular, need to pay more attention to at least three core issues: the quality of citizens' self-perceptions in relation to their local milieu; inter-citizen perceptions and relations at the local level and lastly, the attendant consequences of these on citizens' sense of agency.

The importance of conceptually grasping the interplay of these three issues notwithstanding, there has unfortunately been inadequate conceptual strides within communication for social change scholarship, in particular, to provide an encompassing anchorage through which these three issues could be examined. In a bid to redress this situation, we propose the adoption of Floya Anthias' notion of narratives of location and positionality as a useful conceptual framework that appropriately captures the three issues mentioned above. We argue below that this conceptual framework is laudable for being capable of providing a platform for scholars to capture and outline more contextually-grounded and culturally-sensitive ways of identifying and analysing some of the most central local challenges of participatory development, democracy, and communication in the Global South.

In the discussions that follow, we proceed as follows: we first present an overview of Anthias' arguments and thereafter, to exemplify the cross-cultural heuristic potential in adopting this framework within social change studies of the Global South, we draw on it to discuss some local discourses of positionality in two different contexts: Nepal and Cameroon. During the last two decades, both Nepal and Cameroon have been experiencing significant political, socio-economic, technological, and cultural changes. After several years of civil war in Nepal and one-party rule in Cameroon, both countries are on the cusp of major and contentious transformations towards more democratic political systems.

In addition to having similar youthful populations (about 60 per cent of the population in both countries is less than 25 years old), Nepal and Cameroon are also very multi-ethnic societies entrenched in ethno-regional machinations and corruption. Such similarities notwithstanding, Nepal and Cameroon are also fundamentally different countries, with enormous differences not least in socio-cultural composition (Nepal, unlike Cameroon is a caste-based society) and political experience (Nepal, unlike Cameroon has experienced a decade of civil war). These differences notwithstanding, as we shall see later, in Nepal as 
in Cameroon, the current challenges to entrench participatory processes of development, democracy, and communication for social change revolve significantly around the quality of inter-citizen perceptions and relations at the local level, and Anthias' notion of narratives of location and positionality aptly captures and brings these to light. We begin below with a brief presentation of Anthias' central ideas.

\section{Narratives of location and positionality}

The concept of narratives of location and positionality was originally proposed by Anthias as a solution to the perceived limitations of the "heuristic value" of the concept of "identity", especially with regards to research on ethnicity and migration. According to Anthias, "narratives of location and positionality" is a useful conceptual framework for investigating:

... processes and outcomes of collective identification - that is, the claims and attributions that individuals make about their position in the social order of things, their views of where and to what they belong (and to what they do not belong) as well as an understanding of the broader social relations that constitute and are constituted in this process (Anthias, 2002, p. 491).

As Anthias further explains, such individual claims, understandings, and broader social relations basically constitute stories of and reveal how people position themselves in different social categories such as gender, race, class, and ethnicity, and how they experience social relations and practices around them (Anthias, 2002, pp. 498-499). These narratives, often characterized by "elements of contradiction and struggle", tend to also contain information about the nature of existing social structures in the narrator's social space and the ways in which the narrator experiences and engages with such structures (Anthias, 2002, p. 500; see also Hopkins, 2007).

In a sense, therefore, this perspective focuses on two key issues that are important in the analyses of the nature of and challenges to participatory development, democracy, and communication, especially in marginalized communities in the Global South: location and positionality. The focus on location, as Anthias (2001, p. 634) earlier noted, is a recognition of the importance of the nature of the local context in shaping social experiences, while the focus on positionality points to the intersection between local social structures (such as class, ethnicity, race, and gender) and agency (where and how individuals socially position themselves and engage in social practices) (see also Anthias, 2001, p. 63, 1998, p. 513, and 2008, pp. 15-16).

In some ways, Anthias' discussions resonate with other scholarly discussions on issues, such as, the importance of narratives in development research (see, for instance, Carr, 2010, p. 221; and Gumucio-Dragon, 2009, p. 462); the influence of cultural representations and positioning on individual agency (see, for instance, Silverstone 1999, p. 46; and Ginsburg, 1991, p. 106); and even notions of belonging in general and the politics of belonging in par- 
ticular. With regards to the latter, Yuval-Davis (2006, p. 199), for instance, has argued that discourses about belonging to either social, political, cultural, or economic groups are "not just different categories of social locations but categories that also have a certain positionality along an axis of power, higher or lower than other such categories". Like Anthias argues, Yuval-Davis further points out that the politics of belonging also includes:

...struggles around the determination of what is involved in belonging; in being a member of a community and of what roles specific social locations and specific narratives of identity play in this. As such, it encompasses contestations both in relation to the participatory dimension of citizenship as well as in relation to issues of the status and entitlements such membership entails (Yuval-Davis, 2006, p. 205).

Although significantly aligned conceptually, mainstream discussions on the politics of belonging differ from Anthias' narratives of location and positionality mainly because of the former's overemphasis on territorialism (see in particular Anthias, 2008; Yuval-Davis et al., 2005; and Ceupens \& Geschiere, 2005), while the latter privileges an assessment of the implications of social structures, and positionings on social relations and practices.

Looked at critically, the discussions above on narratives of location, representation, and positionality provide a laudable conceptual framework through which we can grasp the three core issues identified earlier: citizens' self-perceptions in relation to their local milieu; inter-citizen perceptions and relations at the local level and lastly, the attendant consequences of these on citizens' sense of efficacy. The framework allows us to simultaneously incorporate analyses of contextual features (location) and hierarchies (positioning), as well as individual narratives of experiences within these dimensions, in attempts to understand localized dynamics of inclusion or exclusion, citizens' self-perceptions, inter-citizen perceptions, and overall sense among citizens of power or powerlessness (efficacy) in the face of these dimensions and experiences.

Furthermore, the framework also permits a simultaneous inclusion of discourses of positionality from different levels of a community: individual or group; and at micro, meso, or macro levels. For instance, while a core analytical focus could be placed on the democratic implications of narrations of positionality by local citizens (especially from marginalized communities), analytical attention can simultaneously be placed on interrogating discourses of attributed positionality and their democratic implications. As Yuval-Davis et al. (2005, p. 530) point out, such attributed positionalities can also have an impact on how certain segments of a population "see themselves" in terms of "ideas of belonging and otherness" and this may have an important role to play in "determining forms of social engagement and participation".

As outlined above, Anthias' notion of narratives of location and positionality (which she bundles under the term translocational positionality), offers us an encompassing perspective through which we can conceptually grasp and discuss some of the key factors at play that mitigate the entrenchment of participatory development, democracy, and communi- 
cation in the Global South. In particular, the framework orients us to deeply examine local narrations of positionalities (attributed and non-attributed), which can depict narrators' self-perceptions in relation to other individuals, groups, or institutions; their perceptions of and relations with these other individuals, groups or institutions; and their struggles as they deal with social structures that, among others, construct the "grid of power relations within which the different members of the society are located" (Yuval-Davis, 2006, p. 201).

To demonstrate the cross-cultural heuristic potentials of this framework, we next draw on the central tenets of the framework to discuss some localized discourses of positionality in Nepal and Cameroon. We argue that these discourses, "bolaune" in Nepal and "camno-go" in Cameroon, revolve around inter-citizen perceptions and relations and are thus examples of the extent to which discourses of positionalities can reveal key challenges in the entrenchment of participatory development, democracy, and communication in the Global South. Beyond attempting to demonstrate the cross-cultural heuristic potential of narratives of location and positionality, by using it to discuss thematically different examples of local discourses of positionalities in Nepal and Cameroon, the aim is to show its wide thematic relevance in relation to research about processes of social change in the Global South. We begin below with a discussion of "bolaune" discourses in Nepal.

\section{Bolaune discourses in Nepal}

Modern day Nepal is the outcome of drastic and at times violent political contestations, as the country has changed from a monarchy to now a fledging republic. The transition period has been marked by a politically turbulent time, which was exacerbated in 1996 by a Maoist insurgency. The current transition, or the second phase of an overall transition to democracy, if one perceives it as a continuum of change beginning in 1990, was ignited by the second people's movement in 2006 and constituted the final break from 238 years of monarchy as a symbol of sovereignty and national unity.

Years after the end of the civil war, Nepal is still on the cusp of major socio-political changes. The social setting, for instance, has gone from one in which understandings of self and other were derived from the cultural contrasts found in a relatively stable, contained universe of known roles and ways of being, to a society whose current frames of reference are literally of global dimensions. For many in Nepal, traditional features of local culture continue to shape identity: the physical layout of the city and villages with their relatively homogeneous caste communities, traditional occupations associated with family and caste, or minutely defined ritual tasks given to specific family and caste groups in communal festivals.

Yet, for members of these communities, this traditional social fabric is covered by layers upon layers of new meaning systems: new patterns of economies as people migrate or salaried jobs emerge, new ideologies of education, development, the political system, new arenas of public display and expressive culture, the introduction of new material goods, 
and not least, new media and mediated public discourses. Through repeated enactment, embodiment, and growing presence in daily life, these new systems of meaning form slowly hardening structures around Nepal, binding people together in new relationships (e.g., citizenship) without necessarily contesting earlier systems of social meaning (e.g., caste). As citizens navigate through a range of built environments with vastly different histories, they must also negotiate a range of competing and coexisting systems of value and meaning. The meaning and experience of what we can call modernity lies in the daily balancing of the demands and possibilities of transforming social and material contexts against those of deeply rooted cultural milieu of moral values, systems of prestige, and notions of respect.

For example, caste still serves as an important node of claimed identity in Nepal. For the older generation in particular, caste and occupation remain linked, if not directly (e.g., Dalits traditionally work as landless agricultural laborers), then indirectly, such that a person's traditional caste occupation serves as a benchmark below which one refuses to go (e.g., to someone's home), while anything above is deemed acceptable. Similarly, caste-based marriages remain the rule, although this is slowly changing especially among the youth. Yet even while recognizing caste as a key feature of identity, one must acknowledge the influences of modernity. In Kathmandu and other urban areas throughout Nepal, in settings such as schools, offices, suburban residential areas, factories, and even public spaces like busses, shopping malls, restaurants, movie theatres and parks, people seem to be less likely to be influenced by their caste heritage in terms of with whom they work, study and socialize. Thus, in Nepal, as elsewhere, identities are relational and dynamic. They emerge and change over time through individuals' interactions with others, groups, or the state.

\section{Development's encompassment of social experience}

One driving force in modernization is development. Implicit in this development vision is a set of meanings that both justify institutional structures and provide an authoritative way of representing a social world. Unavoidably, where there is a push for progress through development, there is the creation of a state of backwardness. Where there are institutions and experts with answers, there must necessarily be people who have need. Judging from the changes in Nepal, development has proved much more effective as an ideology than as a set of technical solutions. The notion of development in Nepal offers persuasive new frameworks through which social relations and especially social differences are discussed. As a result, development becomes part of people's everyday life in Nepal and not only as an episodic phenomenon manifested for instance in the course of particular development projects in a village. Being part of everyday life in Nepal, discourses of development in Nepal consequently constitute important mechanisms for the structuring and altering of social imaginations. The capacity for these discourses to alter social imaginations resides in the fact that, as Esteva (1992, p. 10) noted, given the "positive meaning" that the word "development" has come to encompass, for "two-thirds of the people on earth", development is 
a "reminder of what they are not. It is a reminder of an undesirable, undignified condition" (emphasis in original).

The Nepali word for development is "bikas", which signifies growth, evolution, just like its English equivalent does. However, in everyday conversations, bikas for the most part means things: especially commodities that come from elsewhere. Stacy Pigg (1992) has aptly explained how the bikas ideology, which was initially meant to unite the nation through the common goal of the struggle to modernize Nepalese society and the economy, has paradoxically turned out to be a logic that also divides the country (both materially and symbolically) into areas of lesser and greater development (bikasit and abikasit, respectively). Not surprisingly, the key axis around which these developmental distinctions arise within Nepal is that of rural and urban society, as well as between the so-called higher and lower castes.

Meanwhile, as a country, Nepal itself is characterized as abikasit in relation to other countries, such as India, which is relatively more bikasit (developed). Pigg (1992) argues that although "development" is embodied in objects (such as new breeds of livestock, water pipes, electricity, videos, schools, commercial fertilizer, roads, and health posts) and as such is quantifiable, with areas being classified as of greater or lesser development depending on how many of these things they have, the essence of development is the relationships that then pertain between these areas and the people who inhabit them. Whilst urban areas are places of "much development" (dherai bikas), rural areas and villages tend to be, at best, places of "little development" (thorai bikas), or even "no development" (bikas chaina). According to Pigg:

...this inverse relation between rural areas and degrees of bikas gives rise to two ways of representing national society and locating oneself in it. One uses the terms of bikas as coordinates to demarcate social territories and pinpoint social positions; the other turns bikas and village into the compass points according to which socially located people oriented themselves (1992, p. 499).

"Development", therefore, in other words, has become one way of categorization and representation in Nepal and some communication and movements across these fissures in the socio-economic landscape are also structured according to the logic of bikasi ideology. These structurations inadvertently have implications for the nature of inter-citizen interactions and perceptions. For instance, by positioning people within the Nepali social space according to their perceived levels of "bikasi,; this discourse, in Althusserian terms (see Althusser, 1971), connotes a sense of "subjective recognition" of power and subordination among the different social and geographic strata in Nepal. As Butler (1997, pp. 2-3) has argued in Foucaultian terms, the internalization of such discourses in a society reproduces cycles of "subjection" and dependency.

In the first author's doctoral research on media and citizenship negotiations in Nepal, for instance, rural Nepalese regularly articulated these internalized discourses of "subjective recognitions", which are prevalent in diverse social practices in the country. When asked 
how decisions on issues of common concern in the community are made, one of the interviewees, Goma' ${ }^{1}$ a Brahman woman in her forties and a social leader in her community said:

We invite all people from the ward and they make us group leader. And they give advice; we do not have drinking water nearby, we do not have a drain channel here, and they are saying we do not have this and that. From that decision we make a program. [WadaKa sabai vaktaharooLai bolaune, uhaharooLe hamiLai group leader Banaunuhunchha, emphases added].

In the interview, Goma utilizes the verb bolaune to explain how she and the community leaders invite the community for meetings. Bolaune is the causative form of the verb bolnu ("to speak") and as a common Nepali word, bolaune is often translated by the value-free term inviting or addressing. However, translating bolaune using more nuanced English captures the social relations embedded in the word: summoning, calling, or hailing. Translated as such, bolaune means "to make someone else to speak."

Given this meaning, bolaune thus becomes a central practice to analyse in attempts to understand the challenges of entrenching participatory democracy, development, and communication in Nepal, because principally, it reveals tensions between the ideas of democratic speech and political consciousness. In discussions tracing the relation between voice, subjectivity, and shifting notions of intimacy, Kunreuther (2009), for instance, has argued that bolaune appears to be a harmless, everyday practice that has little to do with the broader political significance, as the term is used in many contexts to simply refer to the act of calling out to someone on the street or to inviting a friend or relative to a party, a wedding, or one's house. However, in the particular context of a leader of an NGO calling or inviting someone to a meeting, the word carries within it hierarchies of power. The act of calling out to someone, bolaune, constitutes that person as a speaking subject through the speech of another. This calling is also a request for response. A caller anticipates recognition through the participation of the other; they serve to reinforce his or her identity. On a fundamental level then, bolaune is a practice of mutual, but asymmetrical, recognition between citizens, vis-à-vis each other and themselves.

Practices of bolaune produce forms of recognition, speech, and agency. Following Louis Althusser's (1971) notion of interpellation, Kunreuther (2009) suggests that practices of bolaune in some instances are constitutive of caste-based subjectivity and the means by which people position themselves in relation to one another, as the term reveals and defines the hierarchies of caste. Bolaune characterizes a subjectivity defined through relationships of duty and obedience, which characterizes the hierarchies still existing in Nepal. Kunreuther (2009) further argues that the practice of bolaune corresponds to what Louis Althusser (1971) calls "hailing" - a mode of address that establishes a person's subjectivity, and even body, through speech. Hailing, or using Althusser's more technical term interpellation, reveals the discursive nature of identity and subjectivity. 
Interpellation occurs through reiterated forms of address and conventions that delineate a social position. Through interpellation, a person comes to recognize himself or herself not only as an individual, but also as a subject positioned within a social world. Reflecting on Althusser's notion, Judith Butler (1997) argues that:

\begin{abstract}
... interpellation is an address that regularly misses its mark, it requires the recognition of an authority at the same time it confers identity through successfully compelling that recognition. Identity is a function of that circuit, but does not pre-exist it. The mark interpellation makes is not descriptive, but inaugurative. It seeks to introduce a reality rather than report an existing one; it accomplishes this introduction through a citation of existing convention (1997, p. 33, emphasis added).
\end{abstract}

The process of interpellation thus continuously transforms individuals into subjects, even though individuals are always subjects the moment they enter social life. Bolaune does not so much construct a single subject as constitute a social relationship and the subjects formed within it. The practice of bolaune compels the recognition of the caller by the called, thereby creating their differences, their identities, and their subjectivities. It both recognizes someone's presence in the community and marks his other absence and exclusion from the activities in the community. In doing so, it seems to "re-member" a member of a community of which he/she not is member. The excerpt of the interview below, from the first author's doctoral research, further elucidates this point. The interview was conducted with Tilmati $\mathrm{BK}^{3}$, a Dalit woman in her late teens.

Interviewer: And you said that you did not go to the village discussion program, why did you not go there, is that because you dislike it or what?

Tilmati BK: In particular, they do not invite us. They themselves with the head people ${ }^{4}$ are doing everything but they do not call us. [Nimata pani gardainan. Uniharoo thulathula manchheHaroole garchhan ra hamiLai bolaudapani bolaudainan.]

Tilmati BK's statement reaffirms her subjectivity and indicates implicitly she would have expected (or at least wanted) an invitation from "them" (the Brahman and Chhetry leaders). If bolaune is a way to interpellate a Dalit temporarily as a member of a community, the process can only work if Tilmati BK actually begins to act and speak about herself in the same fashion as the Brahmin call to her (hamilai bolaudapani bolaudainan - not invite us), as interpellation rests on the notion that a "speech act brings the subject into being, and then... that very subject comes to speak, reiterating the discursive conditions of its own emergence" (Bell 1999, p. 165).

As Keane (1997) has pointed out, it is not only language that grants recognition in a symbolic world, but also the way language and material objects work together to create social connections and divisions. Keane's analysis, though originally focused on ritual and performative language, can be extended to everyday forms of performative speech and 
practice. The imagined effect suggests that a birth right to be a community leader (Brahman/Chhetry) is what drives Goma to lead and invite the community - even by force if needed.

Interviewer: Do you include all castes in your community's programs, meetings, discussions, and decisions?

Goma: Yes, now in our forest society, we say there have to be Janjati, Dalit, Brahman, Chhetry, but they are not willing to come, so by force we include one from each caste.

The fight against caste inequalities in Nepal by means of quotas and affirmative action has recently been a development strategy of NGOs to assure equal gender representation and inclusion of all ethnic groups in development programs. Goma, for instance, acknowledges this strategy as a new practice by stating that "yes, now in our forest society we are saying there have to be...." (emphases added).

Not surprisingly, this forced approach to deal with issues of community concern is not an appealing way for all the invited. To Tilmati BK, public space is not always a secure space to enter because, as she explains:

....if we go to a friend's home they go inside [the Brahman/Chhetry house] and we [the Dalit] have to stay outside. That makes us feel sad. That time I asked myself the question why this does happens? When we are at home we are like a king so there are no problems, but when I go outside then I feel a little sad' (Tilmati BK).

Although in this quote Tilmati BK talks about access to certain private houses, and not public space per se, her remark suggests "outside" to her has undertones of discomfort, and leaving her house involves the risk that she might be confronted with discrimination. A sense of efficacy and equal societal status, however, would have possibly enabled Tilmati BK to also do the calling and speaking, so she could argue and request the Brahman to respond to her question of why she is not invited inside the house. Instead, bolaune has become a practice and one-way circuit in which there is dominance, wherein the Brahman/Chhetry addresses and the other castes are addressed.

The discussions above show that differential positionings within the Nepali society have implications for inter-citizen perception, relations, and even a sense of efficacy. The practice of bolaune, for instance, underscores the differences within social relations in Nepal along caste lines in particular, and also highlights how problematic it can become in such societies to entrench processes of participatory development, democracy, and communication. In examining the way bolaune operates in Nepal and its potential implications, it can be shown that having the capacity to "make someone to speak" is by definition an indication of the attributions of different individuals according to their "position in the social order of things" and this provides deeper understandings of the "broader social relations that constitute and are constituted in the process" of inter-citizen interactions (Anthias, 2002, p. 491). 
In a country like Nepal, where differences among citizens operate on several levels (not least along caste and levels of bikasi), the narrations above, especially that on bolaune show that inter-citizen perception and relations are a cornerstone in the struggles to democratize Nepal. As we have argued above, the schisms in recurrent practices of these perceptions and relations, especially at the local level, show that there is a need for more grounded understandings of these processes in attempts to comprehend, in a less techno-centric manner, the dynamics and challenges of processes of civic participation, deliberation, and empowerment of disenfranchised and marginalized populations in the Global South

Anthias' notion of narratives of location and positionality arguably serve this purpose elaborately and as shown in the interview excerpts above, narrations from local Nepalese illustrate their positions within the social structures and indicate their role in and experiences of social structures and practices in a way that reconstructs localized dimensions of difference and identity, on the one hand, and hierarchical and social positions, on the other (see Jørgensen \& Philips, 1999, p. 53, for a discussion on how discourses point to and indicate alterations in subject's positionalities). Nepal's long history of caste-based social structures is markedly different from what operates in Cameroon, but as will be shown in the discussions below, like in Nepal, local discourses of positionality in Cameroon are also problematizing processes of entrenchment of participatory democracy and development and the dynamics of these discourses and processes can also be thoroughly examined through Anthias' notion of narratives of location and positionality.

\section{"Cam-no-go" discourses in southwestern Cameroon}

Since the early 1990s, when most countries in sub-Saharan Africa reintroduced multipartism, there has been a marked manifestation of crises of identity and territoriality, which has been bundled by scholars under the notions of "autochthony/allogeny rivalries", or more broadly, the politics of belonging (Geschiere \& Jackson, 2006, p. 2). As the Cameroonian experience shows, the central node of these crises has been the "reinforcement of local identities" in the context of political liberalization and this has given rise to "emotionally-laden oppositions between self-styled 'first settlers' (autochthons)" and those who are seen by these autochthons as 'having come later' (allogenes)" (Socpa, 2006, p. 45). To discuss the manifestations of these "emotionally-laden oppositions", which have revolved around discourses of positionalities, the case of the Southwest Region in Cameroon (SWR), one of the two predominantly English-speaking regions in the country, is examined below.

Modern day Cameroon is a construction of a unique colonial experience, which, to put in brief narrative terms, commenced after Germany colonized the region in 1884. Thirty years after the German occupation, Germany was ousted from Cameroon by the British and French in the course of the First World War. Following their ousting of Germany from Cameroon, France and Britain arbitrarily divided up the territory, with France taking the bulk of it. Britain further partitioned its own territory into two zones: British Southern Cam- 
eroons and British Northern Cameroons, and administered the territories as an integral part of Northern and Eastern Nigeria respectively. On its part, France administered its part of the territory as an overseas part of France under the policy of assimilation.

With the end of the Second World War and mounting pressures for decolonization, France subsequently granted independence to French Cameroun in 1960 as La Republique du Cameroun. One year later, the United Nations sponsored a plebiscite for Cameroonians in British Northern and Southern Cameroons to decide their political fate. While British Northern Cameroonians voted to achieve independence by joining the Federal Republic of Nigeria, British Southern Cameroonians voted to achieve independence by joining the newly independent La Republique du Cameroun. The former territories of British Southern Cameroons now make up the two predominantly English-speaking regions in Cameroon the Southwest and Northwest Regions.

When the Germans colonized Cameroon in 1884, they established several plantations in the SWR, especially around the foot of Mount Cameroon. The establishment of these plantations and shortage of labour in the region led to an influx of people from other regions in Cameroon, as well as from neighbouring Nigeria, to the SWR. Most of these new laborers came from the Northwest Region (NWR) (Eyoh, 1998, p. 269) and an "increasing number gradually decided to settle in the South West after retirement" (Konings, 2001, p. 176).

With their settlement in the SWR, the population of North Westerners in the SWR progressively increased and they later became the "dominant economic force in urban centres" in the region (Eyoh, 1998, p. 269), controlling, in particular, trade, transport, and housing (Konings \& Nyamnjoh, 1997, p. 212; see also Konings, 2001, p. 177). With time, what was initially perceived as a wholly convivial relationship, between South Westerners and North Westerners in the SWR, started giving way to accusations, especially from the political elites of the SWR, that the "settler population" from the NWR were exploitative land-grabbers who are ungrateful to the "welcoming indigenes" (Konings \& Nyamnjoh, 2000, p. 19; see also Nyamnjoh \& Rowlands, 1998, p. 328).

It was within this context of a long history of migration and settlement of North Westerners in the SWR, including the increase in their numbers and the emergence of allegations of exploitation and land-grabbing, that multipartism was reintroduced in Cameroon in 1990 after twenty-four years of one party rule. This new political dispensation, characterized by the emergence of the North West-based Social Democratic Front (SDF) party as the main opposition party in Cameroon, triggered overt concerns among South Westerners, especially among the political elites from the ruling party, that given their numerical strength in the SWR, North Westerners could end up occupying more elected positions in the region than South Westerners. Such concerns, expressed in diverse fora, resuscitated years of pent-up tensions between South Westerners and North Westerners in the SWR and made the region become a central "hotbed of confrontations about autochthony and exclusion in direct relation to national politics" (Geschiere \& Nyamnjoh, 2002, p. 426; see also Konings, 2001, p. 184). 
It is worth mentioning that these tensions and "fear of being out-voted by "strangers" - whatever their origins or the "precise definition of their otherness" (Geschiere \& Gugler, 1998, p. 313), also prevailed in other regions in Cameroon and occasioned problematizations of "conventional assumptions about nationality and citizenship" in Cameroon (Nyamnjoh, 2002, p. 755), since a core focus of political discussions, especially since 1990, has been on questions such as "who can vote where" and "who can be a candidate where" (Bayart et al., 2001, p. 182; see also Geschiere \& Jackson, 2006, p. 4).

The spread of concerns about the political implications of the rising number of "settler populations" across Cameroon was followed by the adoption of a new Constitution in 1996, which stipulated, among other things, that the state shall protect the right of minorities and indigenous populations. Without specifying those who qualify to be considered "minorities" or "indigenous populations", the 1996 Constitution inadvertently gave a "legal cushion" to people in the SWR inimical to the increasing presence of North Westerners in the region.

Buoyed by this legislative cushioning and "angered" by the perceived tendency for North Westerners in the SWR to militate in the North West-based SDF, some South Westerners, especially political elites from the ruling party, have overtly appropriated "political discourses that emphasize ethnic particularities and the importance of localities" (Monga, 2000, p. 723). Thus far, the central discourse has been to call North Westerners in the SWR "cam-nogo", which is a Pidgin English phrase referring to two things: a "visitor who would not leave" and scabies, a "stubborn skin affliction" that is difficult to cure (Konings, 2001, p. 187; see also Ceuppens \& Geschiere, 2005, p. 390; Nkwi, 2006, p. 124; and Farenkia, 2011, p. 1491).

Popularized in 1996 by Governor Oben Peter Ashu of the SWR, these "cam-no-go" discourses, fanned at times by the media (see for instance, Konings \& Nyamnjoh, 2000, p. 27; Konings, 2001, p. 189; and Boyomo, 2002), have led to a further deterioration of relations between South Westerners and North Westerners in the SWR (Konings, 2001, p. 170; Herman, 2006). While the "cam-no-go" discourses have become recurrent in the daily social life of people in the region and are similar to related discourses of belonging across sub-Saharan Africa, its manifest outcomes have not been as violent as those in Ivory Coast or the Democratic Republic of Congo for instance (see Bayart et al., 2001, p. 177; Konings, 2001, p. 191; Geschiere \& Nyamnjoh, 2000, p. 426; Geschiere \& Jackson, 2006, p. 2; and Dunn, 2009, p. 114).

The current non-violent implications of these "cam-no-go" discourses are however corrosive to the long term prospects of entrenching sustainable participatory development and democracy at the local level since what they do is heighten "a politics of belonging at the expense of reforms encouraging both rural and urban participatory 'civil society"' (Nyamnjoh \& Rowlands, 1998, p. 335; see also Ewumbue-Monono, 2001). Therefore, to understand the local "struggles over citizenship" in sub-Saharan Africa (Geschiere \& Jackson, 2006, p. 4) or more broadly contemporary struggles in the region to entrench participatory development and democracy in often multi-ethnic contexts, there is a need to emphasize the role of aspects bordering on inter-citizen perceptions and their implications for inter-citizen interaction. 
It is this emphasis that Anthias' discussions on narratives of location and positionality facilitate both conceptually and empirically. In several ways, the "cam-no-go" discourses fall within the parameters of notions of autochthony/politics of belonging, given their inference to "claims to territory" (Geschiere \& Jackson, 2006, p. 2) and attempts to distinguish between "original inhabitants of the land-the 'sons of the soil' and 'strangers'" (Dunn, 2009, p. 113). While these notions could anchor an analysis of "cam-no-go" discourses for instance, their overemphasis on territorialism blurs the focus that ought to be given to narrations of location and positionality within such contexts, as appropriate gateways to understanding the "contours" of positionality discourses and their implications for inter-citizen perceptions, relations, and sense of efficacy.

Anthias' discussion on narratives of location and positionality has the potential to permit a substantial interrogation of the attributed positionality of North Westerners in the SWR, for instance, through a discursive interpretation of the "claims and attributions" contained in the discourse of "cam-no-go" as well as the "broader social relations that constitute and are constituted" in these process of claims making and "allocation" of attributions (Anthias, 2002, p. 491). More importantly, the framework not only allows us to make sense of and contextualize "cam-no-go" discourses within the confines of local social histories, structure, and place (see Anthias, 2002, p. 500), but it also orients the analytical radar towards an area yet to be substantially explored empirically: getting stories of how North Westerners in SWR position themselves at "specific points in time and space" in the SWR and how they experience the "practices of others" in their localities, and briefly, how they "understand and interpret their place" in the SWR and what implications these have on their sense of efficacy with regards to local processes of development and democracy (see Anthias, 2002, pp. 498-499).

The framework of narrations of location and positionality therefore can serve two central purposes within research on communication for social change: It provides a conceptual framework through which discourses of positionalities and inter-citizen perceptions and relations can be analysed, and also, it orients empirical examinations on processes of social change, since it draws the attention of scholars to pay close attention, while collecting and analysing data, to respondents' narrations of location and positionality as these often straddle between people's perceptions of themselves and others; their relationships with others; their positioning and interactions with social structures; and their sense of efficacy (or agency).

Since a major focus of communication for social change research has been on examining processes of participation at the local level and the empowerment of marginalized communities (implying individual and communal movements along the ladder of efficacy), the narrations of location and positionality framework provides scholars with an entry point to analyse the central variables indicated above that can have an impact on these processes. Also, by obtaining narrations that elucidate narrators' sense of positioning within social spaces and structures and their perceptions of self and collective efficacy, researchers can comprehensively capture local nuances to impediments to participatory development, communication, and democracy; and such perspectives are also invaluable in determining 
the structure, orientation, and depth to give to communication for empowerment interventions.

As Gumucio-Dragon (2009, p. 462) has pointed out, "no one is in a better position to evaluate social change than those that are the subjects of it... [and] they can tell it through their own stories and their own voices". In this regard, it is therefore important for communication for social change scholars to pay closer attention to such stories, since as Carr (2010, p. 219) has argued, they are not merely "windows on indigenous narratives of development", but are rather narratives that reveal how people "position themselves in their experiences", encountered in their social spaces, and can thus "help us to better understand the opportunities and challenges that different interventions present to the emergence of a truly participatory development" in the Global South.

\section{Conclusion}

The central focus of this essay has been to emphasize that in so far as there are several institutional and legislative imperatives for a successful entrenchment of participatory democracy, development, and communication in the Global South, to appropriately capture the challenges of furthering these processes and of empowering marginalized and disenfranchised people and communities, communication for social change scholars need to pay more attention to the following core social relations issues: the quality of citizens' self-perceptions in relation to their local milieu; inter-citizen perceptions and relations at the local level and the attendant consequences of these on citizens' sense of efficacy.

We proposed that Floya Anthias' notion of narratives of location and positionality is a laudable framework that adequately encompasses these core issues and furthers conceptual and empirical discussions on the challenges of entrenching participatory democracy, development, and communication in the Global South. To show the heuristic potential of the framework, we discussed some discourses of positionalities in Nepal (bolaune) and Cameroon (cam-no-go) within the framework and argued that the framework also gives entry points for orienting effective communication for social change interventions.

We have argued that by their very basic nature, participatory approaches to development, democracy, and communication involve parameters of inter-citizen interaction, and as White (1996, p. 6) has argued, such interactions have the potential to both "challenge patterns of dominance and also be a means through which existing power relations are entrenched and reproduced". In the collective scholarly quest to identify and analyse obstacles to participatory development, democracy, and communication in the Global South, it is high time scholars put far more emphasis on collecting and analysing local narratives of location and positionality, as these will provide richer accounts of the nature of local social structures and the "prevalence of inherited social norms that may be working against horizontal dialogue and democratic participation" (Gumucio-Dragon, 2009, p. 456). 


\section{Notes}

1. A pseudonym.

2. The figure of voice activated in this debate suggests thinking about connections between the patterns of recognition established within the subjects of bolaune and the relations emerging between citizen and state during this transformative moment. For historical precedent, one can turn to Richard Burghart's analysis of voice and listening during the monarchical Panchayat regime (1960-1990), when, he suggests, criticism against the state was simultaneously an effort to communicate with the king. He argues that only after the creation of a moral space (which is assumed to be part of civil society in Euro-American liberal democracies) do subjects acquire voice (Burghart, 1996, p. 317).

3. A pseudonym.

4. This refers to the community leaders.

\section{References}

Althusser, L. (1971). Ideology and the ideological state apparatuses (Notes towards an investigation). In Lenin and philosophy and other essays. New York: Monthly Review Press 1971.

Anthias, F. (1998). Rethinking social divisions: Some notes towards a theoretical framework. The Sociological Review, 46(3): 505-535.

Anthias, F. (2001). New hybridities, old concepts: The limits of 'culture'. Ethnic and Racial Studies, 24(4): 619-641.

Anthias, F. (2002). Where do I belong? Narrating collective identity and translocational positionality. Ethnicities, 2(4): 491-514.

Anthias, F. (2008). Thinking through the lens of translocational positionality: An intersectionality frame for understanding identity and belonging. Translocations: Migration and Social Change, 4(1): 5-20.

Barranquero, A. (2009). The state of the art in citizens' communication for social change in Spain. Development in Practice, 19(4-5): 643-653.

Bayart, J-F., Geschiere, P. and Nyamnjoh, F. (2001). Autochtonie, démocratie et citoyenneté en Afrique. Critique Internationale 10: 177-194.

Boyomo, C. (2002). Medias et conflits politiques au Cameroun: Construire la paix par les medias. Rapport de l'attelier 'medias et conflits politiques au Cameroun', 22 Mars 2002, Yaounde.

Brett, E. (2003). Participation and accountability in development management. The Journal of Development Studies, 40(2): 1-29.

Burghart, R. (1996). The conditions of listening. New Delhi: Oxford University Press.

Butler, J. (1997). Excitable speech: A politics of the performative. New York: Routledge.

Carr, E. (2010). The place of stories in development: Creating spaces for participation through narrative analysis. Development in Practice, 20(2): 219-226.

Ceuppens, B. \& Geschiere, P. (2005). Autochthony: local or global? New modes in the struggle over citizenship and belonging in Africa and Europe. Annual Review of Anthropology, 34: 385-407.

Dahlgren, P. (2000). The internet and the democratization of civic culture. Political Communication, 17(4): 335-340.

Docherty, l., Goodlad, R. \& Paddison, R. (2001). Civic culture, community and citizen participation in contrasting neighbourhoods. Urban Studies, 38(12): 2225-2250.

Duun, K. (2009). 'Sons of the soil' and contemporary state making: Autochthony, uncertainty and political violence in Africa. Third World Quarterly, 30(1): 113-127. 
Esteva, G. (1992). Development. In Wolfgang S. (ed.), The development dictionary: A guide to knowledge as power (pp. 6-25). London: Zed Books.

Ewumbue-Monono, C. (2001). Indigenous minorities and the future of good governance in Cameroon: An inquiry into the politics of local governance in the local councils of Fako Division, 1866-2001. Buea: Centre for Research on Democracy and Development in Africa.

Eyoh, D. (1998). Conflicting narratives of Anglophone protest and the politics of identity in Cameroon. Journal of Contemporary African Studies, 16(2): 249-276.

Farenkia, M. (2011). Formes de 'mise a' distance' de l'alterite' ethnique au Cameroun. Journal of Pragmatics, 43: 1484-1497.

Geschiere, P. \& Gugler, J. (1998). The urban-rural connection: Changing issues of belonging and identification. Africa: Journal of the International African Institute, 68(3): 309-319.

Geschiere, P. \& Nyamnjoh, F. (2000). Capitalism and autochthony: The seesaw of mobility and belonging. Public Culture, 12(2): 423-452.

Geschiere, P. \& Jackson, S. (2006). Autochthony and the crisis of citizenship: Democratization, decentralization and the politics of belonging. African Studies Review, 49(2): 1-7.

Ginsburg, F. (1991). Indigenous media: Faustian contract or global village? Cultural Anthropology, 6: 92-112.

Gumucio-Dragon, A. (2009). Playing with fire: Power, participation and communication for development. Development in Practice, 19(4-5): 453-465.

Hermann, A. (2006). Divided societies and ethno-regional antagonisms: A study of the social interaction between Anglophone North Westerners and South Westerners resident in Buea, South West Cameroon. MA Thesis submitted to the Faculty of Social Sciences, University of Troms $\varnothing$, Norway. Retrieved, 6 September, 2011 from: http://www.ub.uit.no/munin/bitstream/handle/10037/142/thesis.pdf?sequence $=1$

Hopkins, P. (2007). 'Blue squares', 'proper' Muslims and transnational networks: Narratives of national and religious identities amongst young Muslim men living in Scotland. Ethnicities, 7(1): 61-87.

Jacobson, T. \& J. Storey. (2004). Development communication and participation: Applying Habermas to a case study of population programs in Nepal. Communication Theory, 14(2): 99-121.

Jørgensen, M. \& Philips, L. (1999). Diskursanalyse som teori og metode. Roskilde: Roskilde Universitetsforlag. Konings, P. (2001). Mobility and exclusion: Conflicts between autochthons and allochtons during political liberalization in Cameroon. In de Bruijn, M. and van Dijk, R. (eds.). Mobile Africa: Changing patterns of movement in Africa and beyond (pp. 169-194). Leiden: Brill.

Konings, P. (2003). Religious revival in the Roman Catholic Church and the autochtony-allochthony conflict in Cameroon. Africa: Journal of the International African Institute, 73(1): 31-56.

Konings, P. \& Nyamnjoh, F. (1997). The Anglophone problem in Cameroon. The Journal of Modern African Studies, 35(2): 207-229.

Konings, P. \& Nyamnjoh, F. (2000). Construction and deconstruction: Anglophones or autochtones? The African Anthropologist, 7(1): 5-32.

Kunreuther, L. (2009). Between love and property: Voice, sentiment and subjectivity in the reform of daughter's inheritance in Nepal. American Ethnologist, 36(3): 545-562.

Monga, Y. (2000). Au village: Space, culture and politics in Cameroon. Cahiers d'Études Africaines, 40(160): 723-749.

Morris, N. (2003). A comparative analysis of the diffusion and participatory models in development communication. Communication Theory, 13(2): 225-248.

Msibi, F. \& Penzhorn, C. (2010). Participatory communication for local government in South Africa: A study of the Kungwini local municipality. Information Development, 26(3): 225-236.

Nelson, D., Folhes, M. \& Finan, T. (2009). Mapping the road to development: A methodology for scaling up participation in policy processes. Development in Practice, 19(3): 386-395. 
Nkwi, W. (2006). Elites, ethno-regional competition in Cameroon and the South West Elites Association (SWELA), 1991-1997. African Study Monographs, 27(3): 123-143.

Nyamnjoh, F. (2002). Local attitudes towards citizenship and foreigners in Botswana: An appraisal of recent press stories. Journal of Southern African Studies, 28(4): 755-775.

Nyamnjoh, F. \& Rowlands, M. (1998). Elite associations and the politics of belonging in Cameroon. Africa: Journal of the International African Institute, 68(3): 320-337.

Pigg, S. (1992). Unintended consequences: The ideological impact of development in Nepal. South Asia Bulletin, 13(1\&2): 45-58.

Rodríguez, C. (2006[2001]). From alternative to citizens' media. In Gumucio-Dagron \& Tufte, T. (Eds.), The communication for social change anthology. Historical and contemporary readings (pp. 762-777). New Jersey: Communication for Social Change Consortium.

Silverstone, R. (1999). Why study the media? London: Sage Publications.

Socpa, A. (2006). Bailleurs autochtones et locataires allogènes: Enjeu foncier et participation politique au Cameroun. African Studies Review, 49(2): 45-67.

Stiglitz, J. (2002). Participation and development: Perspectives from the comprehensive development paradigm. Review of Development Economics, 6(2): 163-182.

Waisbord, S. (2008). The institutional challenges of participatory communication in international aid. Social Identities, 14(4): 505-522.

Webb, K. (1997). Signs of recognition: Powers and hazards of representation in an Indonesian society. Berkeley: University of California Press.

White, S. (1996). Depoliticising development: The uses and abuses of participation. Development in Practice, 6(1): 6-15.

Yuval-Davis, N. (2006). Belonging and the politics of belonging. Patterns of Prejudice, 40(3): 197-214.

Yuval-Davis, N., Anthias, F. \& Kofman, E. (2005). Secure borders and safe haven and the gendered politics of belonging: Beyond social cohesion. Ethnic and Racial Studies, 28(3): 513-535.

Teke Ngomba

PhD student

Department of Aesthetics and Communication

Aarhus University, Denmark imvjnt@hum.au.dk

Jacob Thorsen

PhD student

Department of Aesthetics and Communication

Aarhus University, Denmark jacob@jacobthorsen.net 